\title{
Governance Quality and Information Alignment
}

\author{
Ahmed Elbadry \\ Lecturer, University of Cairo and Visiting Scholar, School of Management, University of Surrey, Guildford, \\ Surrey, UK, GU2 7XH. E-Mail a.abdellatif@surrey.ac.uk.
}

\section{Dimitrios Gounopoulos}

Surrey Business School, University of Surrey, Guildford, Surrey, GU2 7XH, United Kingdom

e-mail:d.gounopoulos@surrey.ac.uk

\section{Frank S. Skinner}

Corresponding author. Surrey Business School, University of Surrey, Guildford, Surrey, GU2 7XH, United Kingdome-mail: f.skinner@surrey.ac.uk, tel +44 148368 6364, Fax +44 1483686346

\begin{abstract}
In this paper we examine the effect of corporate governance mechanisms on asymmetric information. Using a sample of 392 non-financial UK companies listed on the London Stock Exchange, we find that proxies for board independence, board activeness, performance related executive compensation and debt financing are significantly negatively related to the degree of asymmetric information (as reflected in bid-ask spreads, volatility of returns and market price volume of shares traded), whereas ownership concentration is significantly positively related to asymmetric information. The results indicate that the UK companies in our sample have a high degree of compliance with the combined code on corporate governance, and as a result are likely to have higher market values.
\end{abstract}




\section{INTRODUCTION}

In this paper we address the question, to what extent do the governance decisions of listed companies and their shareholders explain the degree of information asymmetry in the market for their shares?

The concept of asymmetric information was introduced in George A. Akerlof's (1970), paper, “The Market for 'Lemons': Quality Uncertainty and the Market Mechanism”. Akerlof relates quality and uncertainty and develops the notion of asymmetric information, using the automobile market ${ }^{1}$ as his example. The main idea in Akerlof's paper is that the parties to a transaction have unequal amounts of information about the other party. Many researchers, in different areas, have explored the concept of asymmetric information and different definitions have emerged depending on the area of application. In (1973) Michael Spence developed the concept of signalling ${ }^{2}$. In 1975 Joseph Stiglitz introduced the idea of screening, which can be used, for example, by an employer to classify individuals into levels that replicate their efficiency or some other ability. Stiglitz (1975) applied this idea to the insurance market, which is characterized by asymmetric information problems, leading to both moral hazard and adverse selection ${ }^{3}$.

\footnotetext{
${ }^{1}$ Akerlof explained that in many markets the buyer uses some market statistic to measure the value of a class of goods. The asymmetry is between the information held by the seller of the used car, for example, and the buyer. Thus, the buyer sees the average of the whole market, while the seller has more knowledge of a specific item. Rosser (2003, p.10) shows that "awareness of their relative ignorance would lead potential buyers to assume that any used car would have a high probability of being low quality, a 'lemon'". On the other hand, Akerlof argues that this information asymmetry provides the seller with a reason to sell goods of less than the average market quality. Then, the average quality of goods in the market will decrease and so will the market size, which can lead to market failure.

${ }^{2}$ In his example, the asymmetry is between an employer and a potential employee. Spence models hiring employees as an investment decision made under uncertainty. The employer is not sure of the characteristics of a person before hiring. Even after hiring the characteristics are not obviously clear, as some job learning and training has to be done. Because the employer is unable to distinguish clearly the skills of the potential employee, he relies on signals (Rosser, 2003). Miller (2002, p.44) argues that "markets with asymmetric information are incomplete because they lack markets for specific levels of product quality. Such markets either lump all qualities together (lemons) or use external indications of quality to separate them (signalling)".

${ }^{3}$ He defines screening as classifying the qualities of goods. The screening mechanism is designed to offer a diversity of deals that encourage agents to disclose accurate information about their riskiness through a process of self-selection. Further, mechanisms or devices that perform screening activities are called screening devices (Rosser, 2003).
} 
Klein et al. (2002) observe that, "in corporate finance, asymmetric information refers to the notion that firm insiders, typically the managers, have better information than do market participants on the value of their firm's assets and investment opportunities". This results in an agency problem. According to agency theory ${ }^{4}$, agency problems arise as a result of the divergence of interests among agents and principals but impose costs only to the extent that principals cannot write perfect contracts (Jensen and Meckling (1976), Shleifer and Vishny (1997), Miller (2002)). Principals cannot write perfect contracts because of asymmetric information concerning the efforts and actions of agents. Because the principals cannot perfectly monitor or measure the behaviour of agents (Haniffa and Hudaib (2006)), agency costs are incurred. They are manifest when the agents (managers) impose additional direct costs on the firm such as personal perquisites or by imposing opportunity costs such as shirking, and by imposing uncertainty in the value of the firm's shares since the existence but not the extent of these agency costs is known to the market (Jensen and Meckling, (1976); Fama and Jensen (1983), Rosser (2003)).

Corporate governance mechanisms are an indirect and probably imperfect tool by which shareholders, as principals, attempt to reduce agency costs by changing the behaviour of managers, who are the agents of the shareholders (Deshmukh (2005), Kanagaretnam et al. (2007); Rutherford and Buchholtz (2007); Chen et al., (2007)). Managers' actions can be changed by mitigating asymmetric information in two ways: by reducing asymmetric information directly through incentives, and by reducing it indirectly through monitoring.

\footnotetext{
${ }^{4}$ The literature has many models and theories related to the concept of asymmetric information. Kennedy et al. (2006) review asymmetric information models in a multi-period setting to explain underpricing in IPOs. These models are signalling, information production, market feedback, entrepreneurial losses, changing objective function, and the information momentum models. Deshmukl (2005) classified the theories of asymmetric information which related to the dividend policy into two theories, pecking order theory and signalling theory. Also, there are two theories that are the closest to the theory of asymmetric information, namely the theory of agency and the theory of incomplete contracts.
} 
Specifically, bonuses may be earned only when managers reveal the level of effort they expend, thereby reducing asymmetric information concerning their actions. In addition, corporate governance mechanisms might reduce asymmetric information indirectly by improving monitoring systems, by splitting the role of the CEO from the chair of the board of directors, or by increasing the number of independent directors on the board. These measures inhibit collusion, and make it more difficult for managers to hide their perquisite consumption and shirking behaviour, while opening a window through which the shareholders view the behaviour of the managers.

There has been limited investigation of the relationship between the nature of the firm's corporate governance and the degree of asymmetric information; much of the evidence that has been acquired is contradictory. Shleifer and Vishny (1997), Perotti and Thadden (2003), Pawlina and Renneboog (2005) and Florackis and Ozkan (2009) find that large shareholders can reduce asymmetric information and improve long-term performance. In contrast, Heflin and Shaw (2000), O'Neill and Swisher (2003) and Fehle (2004) find that greater institutional ownership is associated with greater information asymmetry, as there is a lower degree of informed trading.

Studies that do examine the relation between corporate governance and asymmetric information usually deal with limited aspects, or individual mechanisms, of corporate governance. Cai et al. (2006), Hillier and McColgan (2006), Kanagaretnam et al. (2007) and Holm and Scholer (2010) find that board independence reduces asymmetric information, while Peasnell et al. (2005) suggest that board independence aids the integrity of financial statements. Wruck (1993) and Kang et al. (2006) examine the importance of the form of executive compensation in reducing agency problems and mitigating asymmetric information. Chi and Scott-Lee (2010) and Chen et al. (2010) show that high amounts of free cash flow and external financing needs reduce information asymmetry among firms and strengthen the 
influence of the quality of corporate governance practices on firm value respectively. In contrast, we provide a more comprehensive review of the relationship between corporate governance and asymmetric information by exploring the ability of 18 proxies for corporate governance to explain three measures of asymmetric information.

We have five main hypotheses. The first and second hypotheses are that the more independent and the more active the board of directors, the lower the degree of asymmetric information. Our third hypothesis is that compensation schemes that are designed to enhance performance also reduce asymmetric information. Our fourth hypothesis is that, since inside ownership is presumed to increase agency costs, increases in ownership concentration also increase asymmetric information. The final (fifth) hypothesis is that, since debt financing improves the monitoring of management, it reduces asymmetric information.

We find strong support for all five hypotheses. Proxies related to board independence and board activity, performance-related executive compensation schemes, and debt financing are inversely related to the degree of asymmetric information, whereas proxies related to ownership concentration are directly related to it. Therefore, we are able to address John and Senbet (1998) by finding that governance mechanisms that encourage board independence and greater board activity, greater use of performance-related executive compensation schemes and debt financing, while discouraging ownership concentration, appear to result in a better market outcome. Overall, our results also suggest that the recommendations of the combined code on corporate governance of 2003 regarding board independence and activity and the use of performance-related executive compensation schemes can play a role in reducing the degrees of asymmetric information. Our findings are robust with respect to industry, firm size, and calendar year, and to the use of alternative proxies for board composition, board activity and ownership concentration. 
The remainder of our paper is organized as follows: Section 2 discusses measures of asymmetric information; Section 3 deals with measures of corporate governance and presents the five hypotheses; Section 4 explains the model and sample, and contains descriptive statistics; Section 5 covers data analysis and hypothesis testing. Robustness checks and conclusions are reported in sections 6 and our conclusions are presented in section 7.

\section{MEASURING ASYMMETRIC INFORMATION}

As there is no generally accepted "best" measure of asymmetric information, we choose three that are most commonly used in the literature: the spread ratio, volatility and share volume measured at market prices. ${ }^{5}$ Studies by George et al. (1991), Lin et al. (1995), Madhavan et al. (1997) and Huang and Stoll (1997) analyse the bid-ask spread into its order processing, inventory holding and asymmetric information cost components. However, Van Ness et al. (2001) indicate a strong correlation among all the components of the spread while Menyah and Paudyal (2000) find that, on the London Stock Exchange, the asymmetric information cost component dominates the realised spread. ${ }^{6}$ Taken together, these papers suggest that the adverse selection component behaves in much the same way as the entire spread, and so justifies the use of the bid-ask spread as a proxy variable for asymmetric information. Thus, we expect that the larger the bid-ask spread, the larger the degree of asymmetric information will be.

We follow Kanagaretnam et al. ((2005), (2007)) to calculate the annual bid-ask spread ratio (SPREAD) from observations of the daily closing bid and ask prices for each company

\footnotetext{
${ }^{5}$ There are many other proxies for asymmetric information. For example, Ness, Ness, and Warr (2001) suggest informed trader variables such as the number of analysts covering a given company and the percentage of stock of a given company held by an institution. Kanagaretnam et al. (2005) examine other proxies, specifically earnings forecast dispersion, forecast revision volatility, the level of analyst coverage and the change in share trade depth around quarterly earnings releases.

${ }^{6}$ Menyah and Paudyal (2000) find that on the LSE on average 30\% of the spread is the order processing cost, $23 \%$ is inventory cost and $47 \%$ is the asymmetric information cost.
} 
and year in the sample. This data is collected from Bloomberg. Specifically, the spread ratio for company $\mathrm{i}$ and year $\mathrm{y}$ is

$$
\text { Spread Ratio }_{i, y}=\sum_{\mathrm{t}=1}^{\mathrm{n}}\left[\frac{\mathrm{ASK}_{\mathrm{t}}-\mathrm{BID}_{\mathrm{t}}}{\left(\mathrm{ASK}_{\mathrm{t}}+\mathrm{BID}_{\mathrm{t}}\right) / 2}\right] \times 100 / \mathrm{n}
$$

where $\mathrm{n}$ is the number of trading days $\mathrm{t}$ in year $\mathrm{y}$.

Van Ness et al. (2001) use the average volatility of daily stock returns in addition to the bid-ask spread as a proxy for information asymmetry. Wang (1993) shows that information asymmetry among investors can increase volatility, although Pardo and Torro (2007) and Gray et al. (2009) caution that volatility can overstate the level of asymmetric information. Accordingly, we assume that the higher the average volatility in daily stock return (VOLATILITY), the higher the degree of asymmetric information.

We use share trading volume as our third measure, since Draper and Paudyal ((1999) (2008)) indicate that daily average trading volume, measured at market prices, is inversely related to asymmetric information. According to Van Ness et al. (2001), average trading volume is related to information asymmetry because less is known about less frequently traded stocks. Acker et al. (2002) report that high trading volumes are associated with closing prices more often within the daily spread and indicates lower levels of information asymmetry. Moreover, Tung and Marsden (2000) find increased trading volume in the presence of legally derived private information, but decreased volume in the evident presence of informed insiders. Gajewski (1999) finds that trading volume is larger on announcement days, suggesting that higher trading volumes are associated with the possible release of information. Hence, we expect that the higher the average trading volume (VOLUME), the lower the degree of asymmetric information. 


\section{MEASURING CORPORATE GOVERNANCE}

The main theoretical aim of this paper is to develop hypotheses concerning the influence of corporate governance on the degree of asymmetric information. We develop 18 proxies for corporate governance, grouped into five categories. Specifically, the five categories are board composition, board activity, executive compensation, ownership structure and debt financing. We regress these corporate governance proxies on measures of asymmetric information. We also incorporate two control variables, market capitalization to control for firm size, and industry category to control for industry specific effects. ${ }^{7}$

Fama and Jensen (1983), Denis and McConnell (2003) and Pike et al. (2005) recognize the essential role played by the board of directors in monitoring management. Recently, Becker-Blease and Irani (2008) and Lin et al. (2008) have found that board independence reduces asymmetric information during a seasoned equity offering. Also, Hillier and McColgan (2006) find that firms with a higher proportion of independent directors have superior performance records, resulting in higher share prices. As there is a consensus that independent boards are more effective monitors of management and thereby encourage better performance, we predict that:

H1: Ceteris paribus, there is an inverse relationship between the characteristics of the board that are consistent with standards of best practice for corporate governance and the degree of asymmetric information.

We use eight variables that measure the composition and size of the board of directors. These are the number of directors serving on the (i) remuneration, (ii) nomination and (iii)

\footnotetext{
${ }^{7}$ These variables are defined in Table 2.
} 
audit committees, (iv) the number of non-executive directors, (v) board size, (vi) the presence of a non-executive chairman, (vii) the split in the responsibilities of the CEO and Chairman and (viii) the percentage of females on the board of directors.

According to the UK combined code on corporate governance of 2003, the remuneration, nomination and audit committees should be composed of non-executive directors. Therefore, the larger the committee size, the greater the committees' independence, as larger committees are more likely to include non-executives. Evidently, it is felt that the more these committees are independent of executive control, the more effective these committees will be in exercising good corporate governance. That is, more independent boards can be more exacting monitors of executive behaviour and indirectly can reduce information asymmetry. While there is little empirical evidence regarding the effect of committee size or degree of independence on information asymmetry, Becker-Blease and Irani (2008) report that the size of the audit committee mitigates asymmetric information during a seasoned equity offering. Similarly, Kanagaretnam et al. (2007) indicate that board independence reduces information asymmetry around the time of a quarterly earnings announcement. Accordingly, we expect that the larger the number of directors serving on the remuneration (RCSIZE), nomination (NCSIZE) and audit committees (ACSIZE), the lower the asymmetry. Further, the larger the number of non-executive directors (NONEXESIZE) serving on the board of directors, the greater the board's independence and hence the lower the asymmetry.

Board size (BSIZE) is defined as the number of directors serving on the board. Cai et al. (2006) suggest that the number of directors can influence disclosure activities. Larger boards are more likely to have some independent members, so they are more likely to be more effective monitors of senior management. Therefore, we expect an inverse relation between board size and information asymmetry. 
The corporate governance literature suggests that power should not be concentrated exclusively with one executive, as that executive will tend to dominate the Board of Directors. Accordingly the UK combined code on corporate governance of 2003 recommends that the roles of the chairman of the board and the CEO be split, and that the chairman of the board should not also be an executive. We employ two dummy variables, CEO/Chairman split and non-executive chairman, to gauge the concentration of power in the top ranks of the firm. $\mathrm{CEO} /$ Chairman split is equal to one if the two positions are split and zero otherwise, while non-executive chairman NONEXECHAIR is equal to one if the chairman is a non-executive director and zero otherwise. We expect that splitting the two positions and appointing a nonexecutive chair will lead to less information asymmetry, as there will be more effective monitoring of the CEO at board level.

Finally, Cai et al. (2006) suggest that share prices are more likely to be information efficient when the board includes female directors. Thus we predict that the greater the fraction of females on the board FEMALETOBOARD the lower the degree of information asymmetry.

Kanagaretnam et al. (2007) suggest that boards and committees that meet more frequently are likely to be monitoring management more closely, which should at least indirectly mitigate information asymmetry. Thus, we hypothesis that:

H2: Ceteris paribus, there is an inverse relationship between the level of board activity and the degree of asymmetric information.

We use four variables to measure the activity of the board and its' committees. These are the annual number of meetings of the board (BOARDMEETS), the remuneration committee (RCMEETS), the audit committee (ACMEETS), and the nomination committee 
(NCMEETS). Kanagaretnam et al. (2007) find that the number of board meetings and audit committee meetings are inversely related to the bid-ask spread around the date of a quarterly earnings announcement. We expect this effect to be more wide-spread so that, as the number of meetings increase, the degree of information asymmetry decreases.

Performance-related benefits and bonuses are designed to enhance shareholder value by encouraging managers to reveal the level of effort they expend, and to avoid shirking and consuming perquisites. Wruck (1993) shows that companies with investment disincentives have CEO compensation that emphasizes equity ownership relative to other forms of executive compensation. Camara (2001) suggests that both equity incentives and regular periodic compensation are required to motivate managers to take actions that maximize shareholders' wealth. Shleifer and Vishny (1997) suggest that it is better to grant management long term incentives in order to align management's interests with those of investors. Additionally, according to Kang et al. (2006), equity-based compensation is the most powerful means of aligning the interests of the CEO and shareholders. Compensation packages that reward managerial performance also reduce asymmetric information, because managers are encouraged to reveal the level of effort they expend in order to qualify for performance payments. Thus we hypothesise that:

H3: Ceteris paribus, there is an inverse relationship between compensation schemes that are designed to enhance performance and the degree of asymmetric information.

We use three proxies for executive compensation schemes that are designed to reward performance and thereby to reveal asymmetric information. First, CEO benefits and bonuses ratio (CEOBENEFITS) is defined as the ratio of the CEO's benefits and bonuses to the CEO's total annual income. Since benefits and bonuses are performance-related, we expect 
that the higher the ratio of CEO benefits and bonuses, the lower will be the degree of asymmetric information. Second, CEO long-term mix (CEOLONGCOMP) is a dummy variable that takes the value of 1 if the CEO is remunerated with stock options or payments from the performance plan and 0 otherwise. We expect that long-term incentive schemes will encourage better performance and reduce the degree of asymmetric information. Third, executive benefits and bonuses (BENEFITS) is defined as a dummy variable that takes the value of 1 if executives (other than the CEO) are remunerated with benefits, bonus and stock options and 0 otherwise. We expect that executive benefits and bonuses schemes will encourage better performance and also reduce the degree of asymmetric information.

The effect of ownership concentration on asymmetric information is uncertain. On the one hand, Shleifer and Vishny (1997) and Florackis and Ozkan (2009) suggest that large shareholders are effective in supervising management, while Bozec and Laurin (2008) argue that large shareholders are able to improve long-term performance. Correspondingly, Perotti and Thadden (2003) document that dominant investors such as large lenders or large equity holders can improve corporate governance, and Pawlina and Renneboog (2005) conclude that block-holders appear to play a role in mitigating agency problems.

On the other hand, more block-holders means more concentrated ownership, where blockholders can influence management to take actions in the blockholders' interests and contrary to the interests of the other shareholders. Heflin and Shaw (2000) and O'Neill and Swisher (2003) suggest that greater institutional ownership can cause an increase in adverse selection costs. Dong and Ozkan (2008) note the increasing importance of institutional investors in UK companies, finding that $80 \%$ of shares outstanding are held by financial institutions. A close examination of the annual reports of our sample of UK companies reveals that the majority of block-holders are institutional shareholders, such as pension plans 
and hedge funds. ${ }^{8}$ Thus, the effect of block ownership in the UK capital market should be consistent with the model proposed by O'Neill and Swisher (2003). Therefore, we anticipate that the higher the ratio of block ownership, the larger the degree of asymmetric information. Moreover, we expect that the larger the holding of the largest investor, the larger the degree of asymmetric information. Hence, we hypothesise that:

H4: Ceteris paribus, there is a positive relationship between ownership concentration and asymmetric information.

We use two variables to measure the relation between ownership concentration and asymmetric information. First, percentage block ownership (BLOCKOWN) is defined as the fraction of outstanding shares owned by block-holders such as institutions, families and anchor investors who hold more than $3 \%$ of the shares outstanding. Second, we use the fraction of outstanding shares owned by the largest block-holder (LARGESTOWN).

Debt financing can be viewed as a mechanism to mitigate asymmetric information because creditors are motivated to monitor the behaviour of management in order to protect their claims. Degryse and Jong (2006) state that "leverage, and particularly bank debt, is a key disciplinary mechanism which reduces the managerial discretion problem and asymmetric information problem”. Bebchuk (2003) concurs with this, stating that company debt can act as a disciplinary device to limit managerial discretion and asymmetric information, and works towards aligning manager and shareholder interests. We use the total debt to total assets ratio (DEBTRATIO) as a proxy for the level of debt financing. Lenders monitor the behaviour of managers as they periodically examine compliance with debt covenants. Thus we hypothesise that:

\footnotetext{
${ }^{8}$ We cannot obtain a precise breakdown of block-holders into institutional versus non-institutional, as the details published in the financial statements are sometimes ambiguous. Nevertheless it is clear that, even counting the ambiguous entries as non-institutional, block-holders are dominated by institutional investors.
} 
H5: Ceteris paribus, there is an inverse relationship between levels of debt financing and asymmetric information.

\section{METHODOLOGY AND DATA DESCRIPTION}

The target population is defined as non-financial UK companies listed on the London Stock Exchange. Financial firms are excluded because of extreme differences in their capital structures and regulatory environment compared with other firms. We also exclude firms without annual reports or firms that were first listed after 2003. Table 1 shows that the final sample is comprised of 392 UK firms comprising of industrials (43.62\%), consumer services (20.66\%), technology (10.71\%) and consumer goods $(9.95 \%)$. Since industrials appear to dominate our sample, we later check on the robustness of our results by separately examining industrial and non-industrial firms.

$<<$ Table 1 about here $>>$

The data is collected from the London Stock Exchange, Bloomberg and the company annual reports. From the London Stock Exchange we collect the industry classification of listed companies. Company financial and market data is from Bloomberg and corporate governance data is from the companies' annual reports.

We collect all the data that we could find for all 392 firms annually from 2003 to 2006. This means we collect a panel data series of 392 cross sectional and four annual observations for a potential dataset of 1,568 observations. Unfortunately, we were unable to 
confirm or update the value of all variables. In every year, rather than assuming that the values of such variables were unchanged from the previous year, they were coded as missing.

Our panel has 392 companies, but factors in only 4 years. Under these circumstances we do not use a fixed effects estimator (Judge et al., (1985)). An analysis of variance test does reveal clear evidence of time effects. For these reasons we fit a random and time effects model $^{9}$

Accordingly, we study the effect of corporate governance variables on the degree of asymmetric information using the following three (j) panel regression models on 392 (i) companies of (potentially) 4 (t) time series observations each using a random and time effects estimator.

$$
Y_{j, i, t}=\alpha_{j}+\Sigma \mathrm{B}_{j} \text { Governance Variables }_{\mathrm{j}, \mathrm{i}, \mathrm{t}}+\varepsilon_{j, i, t}
$$

Where:

$\mathbf{j}=\mathbf{1}=$ SPREAD,

$\mathbf{j}=\mathbf{2}=$ VOLATILITY,

$\mathbf{j}=\mathbf{3}=$ VOLUME,

$\boldsymbol{\alpha}=$ Regression intercept

$\boldsymbol{\varepsilon}_{\mathrm{j}, \mathrm{i}, \mathrm{t}}=$ The random error term for each regression $\mathrm{j}$ and company $\mathrm{i}$ and date $\mathrm{t}$.

The definitions of all 18 governance variables and the expected signs of the coefficients are reported in Table 2.

$<<$ Table 2 about here $>>$

\footnotetext{
${ }^{9}$ A fixed effects model would consume 392 degrees of freedom, to allow the constant term to vary by company.
} 
Table 3 Panel A shows that the means of SPREAD, VOLATILITY and VOLUME are $2.44 \%, 32.56 \%$ and approximately 500 million shares per day respectively. These variables exhibit high levels of variability as measured by their standard deviations of 3.43, 19.13 and 1.3 million respectively. Clearly there are large differences in the degree of asymmetric information among UK non-financial companies.

Table 3, Panel B, also shows that many proxies for corporate governance have a large degree of variability possibility because of the large variation in the size of UK companies in our sample. Note the high standard deviation 10,847 of COMPANYSIZE. This large degree of variation among the UK companies' sizes suggest that we have a rich dataset that can explain the large differences in board composition and activeness, compensation plans, ownership structure and debt structure. Later we examine the robustness of our results by company size.

$<<$ Table 3 about here >>

A detailed analysis of the sample indicates that the data is not normally distributed. ${ }^{10}$ A lack of normality together with the possibility of empirical non-linear relationships between the dependent and independent variables and concentrations of the data around certain values lead Cooke (1998) to suggest that in cases such as these the original data be transformed to normal scores using the Van der Waerden (1952) approach. ${ }^{11}$ Using normalised transformations of our data in later regressions has the advantage of preserving monotonicity between the dependent and independent variables, disperses data concentration

\footnotetext{
${ }^{10}$ The results of these normality tests are available from the corresponding author upon request.

${ }^{11}$ Normalization equalizes the intervals between data points by approximating where scores estimated from the underlying data fall along a normal distribution. In the Van der Waerden approach, normal scores are estimated from the underlying data by ranking data points according to the scheme $r /(w+1)$ where $w$ is the sum of the data series and $\mathrm{r}$ is the rank of a given data point. This score is then converted into quantiles of the normal distribution. These quantile scores are then used in the regressions.
} 
and improves the reliability of the standard errors. Accordingly, we transform the continuous dependent and independent variables using normal scores and perform our correlation and regression analysis with the transformed variables, as is found in other papers in the corporate governance literature (Cooke (1998), Haniffa and Cooke (2002) and Mangena and Tauringana (2007)).

\section{DATA ANALYSIS}

Table 4, Panels A and B, provides the Pearson correlations between the corporate governance and asymmetric information variables. In some cases, e.g. between BSIZE and NONEXESIZE, the Pearson correlation exceeds 0.7, thereby indicating a possible collinearity problem. We further examine the extent to which collinearity affects the results by computing the variance inflation factors VIF for each independent variable. The usual rule of thumb is that a VIF of 10 or more is evidence of high collinearity. The results of this analysis along with the obvious collinearity problems evident in later regressions cause us to drop BSIZE, RCSIZE, NCSIZE, RCMEETS, NCMEETS and LARGESTOWN, as all are highly correlated with other, more significant explanatory variables. We also eliminate BENEFITS from the later regressions, as this variable is not statistically significant in any subsequent regression, a point to which we will return later. Subsequently, we replace NONEXESIZE, ACMEETS and BLOCKOWN in the regression models with their corresponding variables that were dropped for collinearity reasons (namely BSIZE, RCMEETS and LARGESTOWN) to check on the robustness of our proxies for board composition, board activity and ownership concentration.

$<<$ Table 4 about here $>>$ 
The regression analysis proceeds in two steps. First we fit the full regression model, and then we fit a reduced regression model by including only those variables that are most significant in the full model. The second step represents our attempt to find a set of corporate governance variables that are particularly effective in minimising asymmetric information.

Table 5 presents the results of the full regression of (1). While all regressions explain the relation between asymmetric information and proxies for corporate governance to some extent, the $\mathrm{R}^{2}$ of the model for SPREAD (about 50\%) is noticeably higher than the explanatory powers of the models for the other two proxies for asymmetric information. It is gratifying to note that, in the 14 instances where a proxy coefficient is statistically significant, 13 have the sign that we expect.

The sole exception is the unexpected sign of BOARDMEETS in the VOLATILITY regression, suggesting that more board meetings are associated with higher levels of asymmetric information. Ex post it may be that uncertain situations require additional board meetings to resolve them.

$<$ Tables 5 about here $>>$

Table 6, Panel A presents reduced form regression models by dropping the proxies SPLIT, NONEXECHAIR, NCSIZE, BOARDMEETINGS, FEMALETOBOARD and CEOLONGCOMP, because Table 5 indicate other proxies for the same hypothesis are of greater statistical significance. We conduct a chi-square test to determine if the joint contribution of these six variables is zero, and find that we are unable to reject this 
hypothesis. ${ }^{12}$ Because these six excluded variables appear to be less important in explaining the relation between corporate governance and asymmetric information, we drop them and focus the remaining analysis on the proxies that do appear to matter, namely NONEXESIZE, ACMEETS, CEOBENFITS, BLOCKOWN and DEBTRATIO.

Table 6 reports that NONEXESIZE, ACMEETS, CEOBENFITS, BLOCKOWN and DEBTRATIO collectively explain 53\% of the SPREAD measure of asymmetric information and $31.2 \%$ of the VOLUME measure. The model for VOLATILITY yields a poorer fit, as this same set of variables explains only $15.8 \%$ of the VOLATILITY measure.

$<<$ Table 6 about here $>>$

As an additional step, we re-estimated the model of Table 6, Panel A with an alternative specification that replaces NONEXESIZE, ACMEETS and BLOCKOWN with BSIZE, RCMEETS and LARGESTOWNER. This additional regression yields the same conclusions. Specifically, as can be seen in Table 6, Panel B, the alternative proxies for board independence (BSIZE), board activeness (RCMEETS) and ownership structure (BLOCKOWNER) are significantly related to asymmetric information.

Overall, we find that the number of non-executive directors serving on the board, the number of audit committee meetings per year, the ratio of CEO benefits to total CEO income, the fraction of outstanding shares held by block-holders and the total debt ratio are the most important factors in mitigating asymmetric information in the UK capital market. This result is one answer to John and Senbet's (1998) query regarding what would be a more effective set of governance mechanisms that constitutes an optimal governance structure. We now turn to formal tests of our five hypotheses.

\footnotetext{
${ }^{12}$ We exclude the results of this simple test for the sake of brevity. They are available from the corresponding author on request.
} 


\section{(i) Board Characteristics and Board Activity}

Evidently, NONEXESIZE dominates all other proxies for board characteristics. For all measures of asymmetric information, Table 5 and Table 6 Panel A show that the larger the number of non-executive directors on the board, the lower the degree of asymmetric information. Therefore, we find strong support for our first hypothesis, namely that best practice for corporate governance, in this instance more outside representation on the board of directors, does reduce the degree of asymmetric information.

All of the other board characteristics (SPLIT, NONEXECHAIR and NCSIZE) only occasionally exhibit a significant relation with asymmetric information, suggesting that the number of non-executive directors is the most consistent measure of board independence and dominates the other board characteristics as proxies for it. A possible explanation for this result is that there is already a high degree of compliance with the UK combined code on corporate governance of 2003 , so there is insufficient variation in these components to explain variation in the measures of asymmetric information. The variable SPLIT in Table 3 shows that during the sample years from 2003 to 2006, $90 \%$ of the UK companies in the sample separated the roles of Chairman and CEO. Similarly the variable NONEXECHAIR shows that $71 \%$ of the UK companies in the sample had a non-executive director as Chairman. Finally, most of the UK companies in our sample had remuneration, audit and nomination committees as recommended by the combined code. Specifically, of the 392 companies in our sample, 387 had remuneration, 385 had nomination and 388 had audit committees for at least one year in the sample. Moreover, NONEXESIZE is roughly half of BSIZE, suggesting that the remuneration, nomination and audit committees are dominated by outside directors. These results are consistent with a high level of compliance with the 
combined code, since according to the code these committees should be composed of at least 3 independent non-executive directors.

Another board composition variable is worthy of discussion. We find no significant relation between female representation on the board of directors (FEMALTOBOARD) and measures of asymmetric information. Cai et al. (2006) suggest that the presence of female directors would lessen information asymmetry. Again, the descriptive statistics of Table 3 Panel B offer an explanation. The mean of FEMALTOBOARD is $18 \%$. This result suggests that there was a low level of representation of females on boards of directors, so the influence of female representation on asymmetric information was also weak for this sample of companies and in these years.

We have support for the second hypothesis, that active boards reduce asymmetric information. ACMEETS is significantly related to SPREAD and BOARDMEETS is significantly related to VOLUME, meaning that the higher the number of audit committee and board meetings, the lower the degree of asymmetric information.

\section{(ii) Executive Compensation}

We find strong support for our third hypothesis, namely that compensation schemes that are designed to encourage performance also reduce asymmetric information: CEOBENEFITS is highly significant when using SPREAD and VOLUME as the measures of asymmetric information. We note that the average of CEOBENEFITS, as reported in Table 3 Panel B, is $35.03 \%$. This result reflects compliance of UK companies with the combined code since the combined code recommends that a significant portion of executive compensation should be related to performance.

Given the significance of CEOBENEFITS, it is surprising that CEOLONGCOMP and BENEFITS are not statistically significant. The descriptive statistics of Table 3 Panel B offer 
an explanation, because $91 \%$ and $92 \%$ of our sample respectively use long-term compensation plans to compensate the CEO and performance related pay schemes to compensate non-CEO executives. Consequently, since CEOLONGCOMP and BENEFITS are dummy variables, virtually all entries in our dataset are one, so that there is insufficient variation in the data to detect an effect.

\section{(iii) Ownership Structure}

Our fourth hypothesis states that asymmetric information increases with ownership concentration and an element of the literature suggests that this relation can be affected by the type of investor as well. We find that BLOCKOWN is highly significant when using SPREAD, VOLATILITY and VOLUME as measures of asymmetric information. Rather than reducing asymmetric information by increasing the level of monitoring of senior management, these results consistently show that greater share ownership concentration by block-holders is associated with more, not less, information asymmetry. By reviewing the names of block-holders in our sample as reported by the companies' annual reports and in the Bloomberg database, we find that, consistent with Dong and Ozkan (2008), a substantial majority of the blockholders are institutional investors. This result implies that the increasing concentration of block-holdings by UK institutional investors, as noted by Dong and Ozkan (2008), has increased the degree of asymmetric information.

\section{(iv) Debt Financing}

Finally, we find support for our fifth hypothesis, namely, that asymmetric information decreases in debt financing. Our proxy for debt financing (DEBTRATIO) is statistically significant and of the correct sign when we use SPREAD or VOLATILITY as the measure of asymmetric information. This result suggests that debt financing also serves as a 
mechanism for reducing asymmetric information, because lenders monitor the behaviour of managers as they periodically examine compliance with debt covenants.

\section{ROBUSTNESS}

Tables 7 and 8 present the results of our robustness checks. We examine the robustness of our results by examining the year of analysis, differences in the results for small and large companies, and differences between industrial and non-industrial companies. We examine the results by calendar year because we explore if any annual effect is driving our results. We examine the difference among small and large companies because we suspect that small companies may focus on different corporate governance mechanisms. In order to do this, companies are classified as large when they have a market capitalization greater than the median of $£ 309$ million, and small when market capitalization is less than the median. Finally, because a large number of companies in the sample are concentrated in the industrial sector, we check to see whether industry classification dictates the results for the entire sample.

$<<$ Table 8 about here $>$

We use the SPREAD as the proxy measure for asymmetric information in our robustness work because our earlier results suggest that SPREAD is a useful measure for asymmetric information. Also, we use the most significant corporate governance variables (as reported in Table 6, Panel A) because, collectively, they are the most influential when explaining asymmetric information in the UK. We repeat our robustness analysis in Tables 7 
Panel B and Table 8 Panel B, using the same alternative corporate governance variables previously used in Table 6 Panel B.

In general, Table 7 Panel A and B and Table 8 Panel A and B show that our results are not affected by the calendar year or by the industry, but we do find a firm size effect. In particular, we find that our proxy for debt financing (DEBTRATIO) is significant for small companies but not for large companies. One explanation for this result is that small firms face a greater hurdle and may well have to agree to more stringent monitoring in order to qualify for greater debt financing.

\section{SUMMARY AND CONCLUSION}

Using a sample of 392 non-financial UK companies listed on the London Stock Exchange from 2003 to 2006, we examine the effect of corporate governance mechanisms on asymmetric information. While corporate governance mechanisms are designed to mitigate agency costs, they may accomplish this by reducing asymmetric information. This can happen directly through incentives that encourage managers to reveal information concerning their level of effort and perquisite consumption, in order to qualify for incentive payments. This can also happen indirectly, as many corporate governance mechanisms are designed to improve monitoring, making it difficult for managers to conceal the extent of their shirking and of their perquisites consumption.

In general, we find strong evidence that there is indeed an inverse relation between best practice corporate governance mechanisms and asymmetric information. Specifically, we find that independent and active boards, a greater reliance on performance related payment systems, and the use of debt financing all reduce asymmetric information, whereas greater ownership concentration is associated with increased information asymmetry. The 
results are robust to a variety of proxies for these corporate governance mechanisms, and to a variety of measures of asymmetric information. The results are also robust to the year of analysis, to a sample of industrial versus non-industrial firms, and, for the most part, to the size of the firm. Moreover, we find that the number of non-executive directors serving in the board, the number of audit committee meetings per year, the ratio of CEO benefits to total CEO income, the fraction of outstanding shares held by block-holders and the total debt ratio are the most important factors in mitigating information asymmetry in the UK capital market. 


\section{References}

Acker, D., M. Stalker, and I. Tonks. (2002). "Daily closing inside spreads and trading volumes around earnings announcements." Journal of Business Finance \& Accounting, Vol. 29, pp. 1149-1179.

Akerlof, G. (1970). "The market for Lemons: Qualitative uncertainty and the market mechanism." Quarterly Journal of Economics, Vol. 84, No. 3, pp. 488-500.

Bebchuk, L. and J. Fried (2003). "Executive compensation as an agency problem." Journal of Economic Perspectives, Vol. 17, pp. 71-92.

Becker-Blease, J. and A. Irani (2008). "Do corporate governance attributes affect adverse selection costs? Evidence from seasoned equity offerings." Review of Quantitative Finance and Accounting, Vol. 30, No. 3, pp. 281-296.

Bozec, Y. and C. Laurin (2008). "Large Shareholder Entrenchment and Performance: Empirical Evidence from Canada." Journal of Business Finance \& Accounting, Vol. 35, No. 1, pp. 25-49.

Cai, C., K. Keasey, and H. Short (2006). "Corporate governance and information efficiency in security markets." European Financial Management, Vol. 12, pp. 763-787.

Camara, A. (2001). "The pricing of relative performance based incentives for executive compensation." Journal of Business Finance \& Accounting, Vol. 28, No. 9, pp. 1115-1139.

Chen, W. P., H. Chung, T.L., Hsu, and S. Wu (2010). "External financing needs, corporate governance, and firm value." Corporate Governance: An International Review, Vol. 18, No. 3, pp. 234-249.

Chen, W. P., H. Chung, C. Lee, and W.L. Liao, (2007). "Corporate governance and equity liquidity: analysis of S\&P transparency and disclosure rankings." Corporate Governance: An International Review, Vol. 15, pp. 644-660.

Chi, J. D. and D. S. Lee (2010). "The conditional nature of the value of corporate governance." Journal of Banking \& Finance, Vol. 34, pp. 350-361.

Cooke, T. (1998). "Regression analysis in accounting disclosure studies." Accounting and Business Research, Vol. 28, pp. 209-224.

Degryse, H. and A. De Jong (2006). "Investment and internal finance: Asymmetric information or managerial discretion?" International Journal of Industrial Organization, Vol. 24, pp. 125-147.

Denis, D. and J. McConnell (2003). "International corporate governance." Journal of Financial and Quantitative Analysis, Vol. 38, pp. 1-36.

Deshmukh, S. (2005). "The effect of asymmetric information on dividend policy." Quarterly Journal of Business \& Economics, Vol. 44, pp. 107-127.

Dong, M. and A. Ozkan (2008). "Institutional investors and director pay: An empirical study of UK companies." Journal of Multinational Financial Management, Vol. 18, No. 1, pp. 16-29.

Draper, P. and K. Paudyal (1999). "Corporate takeovers: mode of payment, returns and trading activity." Journal of Business Finance \& Accounting, Vol. 26, No.(1 \& 2), pp. 521-558.

Draper, P. and K. Paudyal (2008). "Information asymmetry and Bidders' Gains." Journal of Business Finance \& Accounting, Vol. 35, pp. 376-405.

Fama, E. and M. Jensen (1983). "Separation of ownership and control." Journal of Law and Economics, Vol. 88, pp. 288307.

Fehle, F. (2004). "Bid-ask spreads and institutional ownership." Review of Quantitative Finance \& Accounting, Vol. 22, pp. 275-292.

Florackis, C. and A. Ozkan (2009). "The Impact of Managerial Entrenchment on Agency Costs: An Empirical Investigation Using UK Panel Data." European Financial Management Vol. 15, No. 3, pp. 497-528.

Gajewski, J. (1999). "Earnings announcements, asymmetric information, trades and quotes." European Financial Management, Vol 5, No. 3, pp. 411-424.

George, T., G. Kaul, and M. Nimalendran (1991). "Estimation of the bid-ask spread and its components: a new approach." Review of Financial Studies, Vol. 4, pp. 623-656.

Gray, P., P. S. Koh, and Y.H. Tong (2009). "Accruals Quality, Information Risk and Cost of Capital: Evidence from Australia." Journal of Business Finance \& Accounting, Vol. 36, No. 1-2, pp. 51-72.

Haniffa, R. and T. Cooke (2002). "Culture, corporate governance and disclosure in Malaysian corporations." Abacus, Vol. 38 , pp. 317-349.

Haniffa, R. and M. Hudaib (2006). "Corporate governance structure and performance of Malaysian listed companies." Journal of Business Finance \& Accounting, Vol. 33, pp. 1034-1062.

Heflin, F. and S. K. Shaw (2000). "Blockholder ownership and market liquidity." Journal of Financial and Quantitative Analysis Vol. 35, No. 4, pp. 621-633.

Hillier, D. and P. McColgan (2006). "An analysis of changes in board structure during corporate governance reforms." European Financial Management, Vol. 12, No. 4, pp. 575-607.

Holm, C. and F. Schøler (2010). "Reduction of asymmetric information through corporate governance mechanisms - The Importance of ownership dispersion and exposure toward the international capital market." Corporate Governance: An International Review, pp 18, Vol. 1, pp. 32-47.

Huang, R. and H. Stoll (1997). "The components of the bid-ask spread: a general approach." Review of Financial Studies, Vol. 10, pp. 995-1034.

Jensen, M. and W. Meckling (1976). "Theory of the firm: Managerial behaviours agency costs and ownership structure." Journal of Financial Economics, Vol. 3, No. 4, pp. 305-360.

John, K. and L. Senbet (1998). "Corporate governance and board effectiveness." Journal of Banking and Finance, Vol. 22, pp. 371-403.

Judge, G., W. Griffiths, R. Hill, H. Lutkepohl, and Lee T., (1985). The theory and practise of econometrics Wiley. 
Kanagaretnam, K., G. Lobo, and D. Whalen (2005). "Relationship between analyst forecast properties and equity bid- ask spreads and depths around quarterly earnings announcements." Journal of Business Finance \& Accounting, Vol. 32, No. $9 \& 10$, pp. 1773-1799.

Kanagaretnam, K., G. Lobo, and D. Whalen (2007). "Does good corporate governance reduce information asymmetry around quarterly earnings announcements?" Journal of Accounting and Public Policy, Vol 26, No 4, pp. 497-522.

Kang, S., P. Kumar, and H. Lee (2006). "Agency and corporate investment: the role of executive compensation and corporate governance." Journal of Business, Vol. 79, No. 3, pp. 1127-1147.

Klein, L., T. O'Brien, and S. Peters (2002). "Debt vs. equity and asymmetric information: A Review." Financial Review, Vol. 37 pp. 317

Lin, J., G. Sanger, and G. Booth, (1995). "Trade size and components of the bid-ask spread." Review of Financial Studies, Vol. 8, pp. 1153-1183.

Lin, Y. M., S. J. You, and F.J. Lin (2008). "The Effects of Pre-issue Information Releases on Seasoned Equity Offerings." Journal of Business Finance \& Accounting, Vol. 35, No. 9, pp. 1138-1163.

Madhavan, A., M. Richardson, and M. Roomans (1997). "Why do security prices change? A transaction-level analysis of NYSE stocks." Review of Financial Studies , Vol. 10, No. 4, pp. 1035-1064.

Mangena, M. and V. Tauringana (2007). "Disclosure, corporate governance and foreign share ownership on the Zimbabwe Stock Exchange." Journal of International Financial Management and Accounting, Vol. 18, No. 2, pp. 53-85.

Menyah, K. and K. Paudyal (2000). "The components of bid-ask spreads on the London Stock Exchange." Journal of Banking and Finance, Vol. 24, No 11, pp. 1767-1785.

Miller, R. M. (2002). "Can markets learn to avoid bubbles?." Journal of Psychology \& Financial Markets, Vol.3, pp. 44-52.

O'Neill, M. and J. Swisher (2003). "Institutional investors and information asymmetry: an event study of self-tender offers." Financial Review, Vol. 38, No. 2, pp. 197-211.

Pardo, A. and H. Torró (2007). "Trading with asymmetric volatility spillovers " Journal of Business Finance \& Accounting Vol. 34, No. 9, pp. 1548-1568.

Pawlina, G. and L. Renneboog (2005). "Is investment-cash flow sensitivity caused by agency costs or asymmetric information? Evidence from the UK." European Financial Management, Vol.11, No. 4, pp. 483-513.

Peasnell, K., P. Pope, and S. Young (2005). "Board monitoring and earnings management: Do outside directors influence abnormal accruals." Journal of Business Finance \& Accounting, Vol. 32, No. 7, pp. 1311-1346.

Perotti, E. and E. Ludwig von Thadden (2003). "Strategic transparency and informed trading: will capital market integration force convergence of corporate governance?" Journal of Financial and Quantitative Analysis, Vol. 38, No.1, pp. 61-85.

Pike, R., N. Cheng, K. Cravens, and D. Lamminmaki (2005). "Trade Credit Terms: Asymmetric Information and Price Discrimination Evidence From Three Continents." Journal of Business Finance \& Accounting, Vol.32, No. 5, pp. 1197-1236.

Rosser, A. (2003). Coalitions, convergence and corporate governance reform in Indonesia. Third World Quarterly - Journal of Emerging Areas., Vol. 24, pp. 319-337.

Rutherford, M. and A. Buchholtz (2007). "Investigating the relationship between board characteristics and board information." Corporate Governance: An International Review, Vol. 15, pp. 576-584.

Shleifer, A. and R. Vishny (1997). "A survey of corporate governance." Journal of Finance, Vol. 52, pp 737-783.

Spence, M. (1973). "Job market singaling." Quarterly Journal of Economics, Vol. 87, No. 3, pp. 355-374.

Stiglitz, J. (1975). "The theory of screening, education, and the distribution of Income." American Economic Review, Vol. 65, pp. 283-300.

Tung, Y. and J. Marsden (2000). "Trading volumes with and without private information: A study using computerized market experiments." Journal of Management Information Systems, Vol. 17, No. 1, pp. 31-57.

Van der Waerden, B. L. (1952). Order tests for the two-sample and their power. Koninklijke Nererlandse Akademie Van Welenscehappen.

Van Ness, B., R. Van Ness, and R. Warr (2001). "How well do adverse selection components measure adverse selection?" Financial Management, Vol. 30, pp. 77-98.

Wang, J. (1993). "A model of inter-temporal asset prices under asymmetric information." Review of Economic Studies Vol. 60, pp. $249-282$.

Wruck, K. (1993). "Stock-based incentives and investment decisions." Journal of Accounting \& Economics, Vol. 16, No. 1-3, pp. 373-380. 
Table 1

Sample composition according to industry, number of companies, and the percent of each industry to total sample

\begin{tabular}{lll}
\hline Main-Industry & Number & $\%$ \\
\hline Basic Materials & 19 & 4.85 \\
Consumer Goods & 39 & 9.95 \\
Consumer Services & 81 & 20.66 \\
Health Care & 19 & 4.85 \\
Industrials & 171 & 43.62 \\
Oil \& Gas & 8 & 2.04 \\
Technology & 42 & 10.71 \\
Telecommunication & 5 & 1.28 \\
Utilities & 8 & 2.04 \\
Total & 392 & 100.00 \\
\hline
\end{tabular}

Notes: The target population includes all non-financial UK companies listed on the London Stock Exchange during the period 2003 to 2006. The names and main industry of these companies are from the London Stock Exchange. 
Table 2

Variables and Definitions

Variable (relation with

Definition

asymmetric information)

SPREAD (+)

VOLATILITY (+)

VOLUME (-)

BSIZE (-)

NONEXESIZE (-)

SPLIT (-)

NONEXECHAIR (-)

RCSIZE (-)

NCSIZE (-)

ACSIZE (-)

BOARDMEETS (-)

RCMEETS (-)

ACMEETS (-)

NCMEETS (-)

FEMALETOBOARD (-) CEOBENEFITS (-)

CEOLONGCOMP (-)

BENEFITS (-)

BLOCKOWN (+)

LARGESTOWN $(+)$

DEBTRATIO (-)

COMPANYSIZE $(-)$

\section{Asymmetric information variables}

The annual mean value of the daily percentage spread between bid and ask prices

The annual average standard deviation of the day-over-day difference in the daily price change

The annual average of daily market value of trading volume

\section{Corporate governance variables}

The number of directors serving on the board of directors

The number of non-executives serving on the board of directors

A dummy variable that takes on a value of one if the CEO and Chairman are different persons, zero otherwise

A dummy variable that takes on a value of one if the chairman is a nonexecutive, zero otherwise

The number of directors serving on the remuneration committee

The number of directors serving on the nomination committee

The number of directors serving on the audit committee

The number of board meetings per annum

The number of remuneration committee meetings per annum

The number of audit committee meetings per annum

The number of nomination committee meetings per annum

The percentage of the board of directors when are female

The ratio of annual benefits and bonuses to CEO total annual income

A dummy variable that takes on a value of one if the CEO is remunerated with stock options or payments from performance plans, zero otherwise

A dummy variable that takes on a value of one if executives other than the CEO are compensated with benefits, bonuses, stock options or payments from performance plans, zero otherwise

The fraction of outstanding shares owned by block-holders

The fraction of outstanding shares owned by the largest block-holder

The ratio of total debt to total assets

The market capitalization of the firm

Notes: SPREAD = (ASK - BID)/ ((ASK + BID)/ 2) * 100. The annual average of the daily bid and ask prices and VOLATILITY, VOLUME, DEBTRATIO, BLOCKOWN and LARGESTOWNER are from Bloomberg and the rest of the corporate governance variables are from the companies' annual reports. 
Table 3

Descriptive Statistics

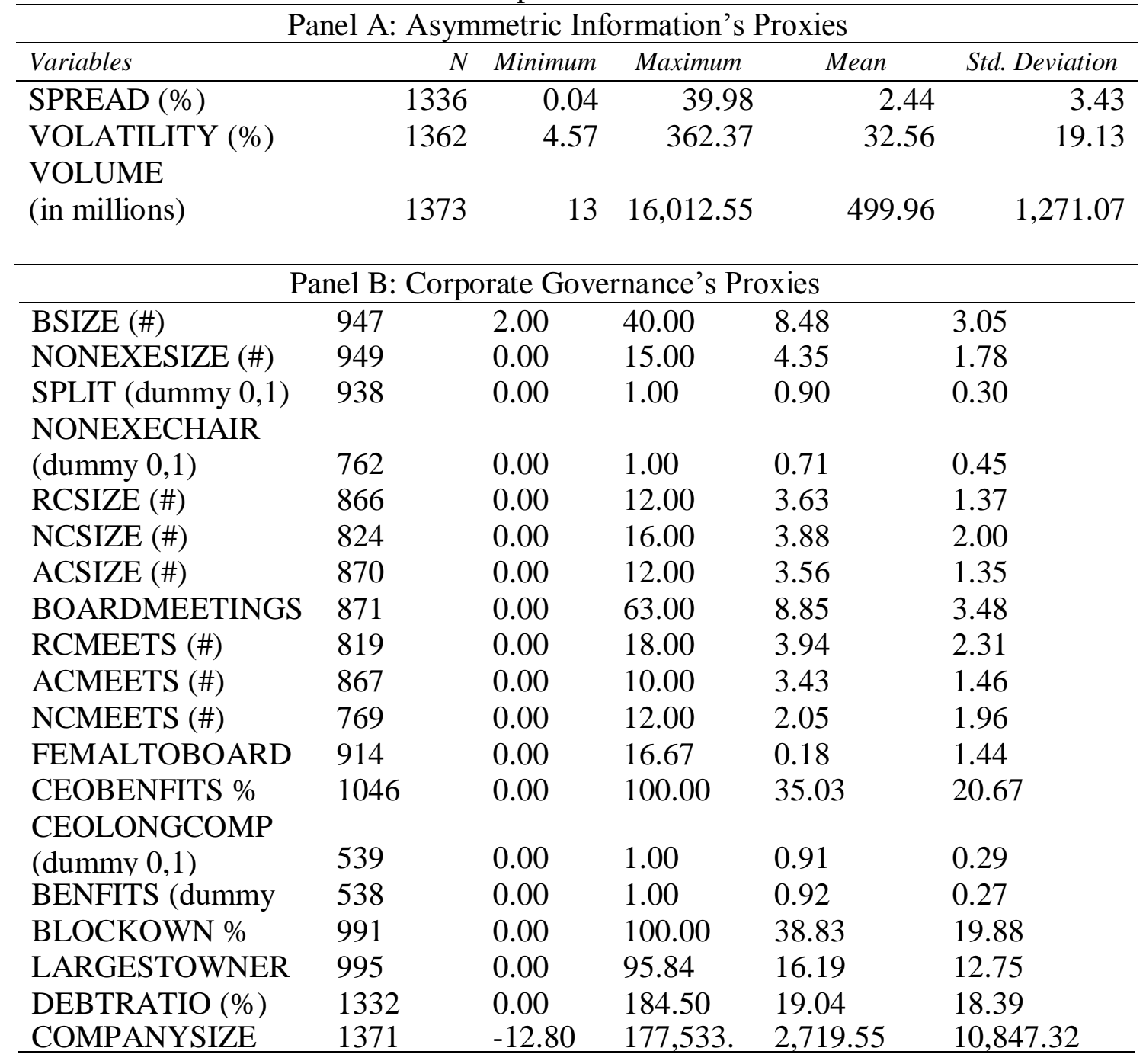


Table 4

Pearson correlations between the corporate governance and asymmetric information variables, using the normal score for all continuous variables

Panel A: Pearson correlations between corporate governance variables

\begin{tabular}{|c|c|c|c|c|c|c|c|c|c|c|c|c|c|c|c|}
\hline & & 1 & 2 & 3 & 4 & 5 & 6 & 7 & 8 & 9 & 10 & 11 & 12 & 13 & 14 \\
\hline 1 & BSIZE & 1.000 & & & & & & & & & & & & & \\
\hline 2 & NONEXESIZE & $0.740^{* * * *}$ & 1.000 & & & & & & & & & & & & \\
\hline 3 & RCSIZE & $0.479^{\text {***** }}$ & $0.497^{* * *}$ & 1.000 & & & & & & & & & & & \\
\hline 4 & NCSIZE & $0.328^{* * * *}$ & $0.327^{* * *}$ & $0.497^{* * * *}$ & 1.000 & & & & & & & & & & \\
\hline 5 & ACSIZE & $0.459^{* * * *}$ & $0.501^{* * *}$ & $0.745^{* * * *}$ & $0.389^{* * * *}$ & 1.000 & & & & & & & & & \\
\hline 6 & BOARDMEETINGS & $-0.091^{* * *}$ & -0.051 & $0.074^{*}$ & 0.014 & 0.005 & 1.000 & & & & & & & & \\
\hline 7 & RCMEETS & $0.286^{* * * *}$ & $0.309^{* * * *}$ & $0.309^{* * * *}$ & $0.262^{* * * * *}$ & $0.279^{* * * *}$ & $0.170^{* * *}$ & 1.000 & & & & & & & \\
\hline 8 & ACMEETS & $0.365^{* * * *}$ & $0.403^{* * *}$ & $0.305^{* * * *}$ & $0.248^{* * * *}$ & $0.306^{* * *}$ & 0.070 & $0.435^{* * * *}$ & 1.000 & & & & & & \\
\hline 9 & NCMEETS & $0.297^{* * * *}$ & $0.285^{* * * *}$ & $0.251^{* * * 4}$ & $0.410^{* * * *}$ & $0.254^{* * *}$ & 0.071 & $0.451^{* * * *}$ & $0.394^{* * *}$ & 1.000 & & & & & \\
\hline 10 & FEMALTOBOARD & 0.078 & 0.066 & $0.097^{*}$ & $0.093^{*}$ & 0.077 & 0.044 & $0.154^{* * * *}$ & 0.034 & 0.040 & 1.000 & & & & \\
\hline 11 & CEOBENFITS & $0.209^{* * * *}$ & $0.204^{* * *}$ & $0.164^{* * * *}$ & $0.136^{* * *}$ & $0.160^{* * *}$ & 0.001 & $0.174^{* * *}$ & $0.196^{* * *}$ & $0.175^{* * *}$ & 0.062 & 1.000 & & & \\
\hline 12 & BLOCKOWN & $-0.186^{* * * *}$ & $-0.122^{* * * *}$ & -0.078 & $-0.134^{* * * * *}$ & $-0.128^{* * * *}$ & 0.040 & $-0.238^{* * * *}$ & $-0.166^{* * * *}$ & $-0.176^{* * * *}$ & 0.012 & $-0.117^{* *}$ & & & \\
\hline 13 & LARGESTOWNER & $-0.136^{* * * *}$ & $-0.103^{* * *}$ & $-0.137^{* * * *}$ & $-0.157^{* * * *}$ & $-0.177^{* * *}$ & -0.066 & $-0.223^{* * *}$ & $-0.147^{* * *}$ & $-0.188^{* * *}$ & 0.040 & $-0.133^{* * *}$ & $0.780^{* * * *}$ & 1.000 & \\
\hline 14 & COMPANYSIZE & $0.556^{* * * *}$ & $0.607^{* * * *}$ & $0.373^{\text {**** }}$ & $0.269^{* * * *}$ & $0.390^{* * * *}$ & 0.020 & $0.295^{* * * *}$ & $0.451^{* * *}$ & $0.305^{* * *}$ & $0.094^{\text {*** }}$ & $0.362^{* * *}$ & $-0.286^{* * * *}$ & $-0.246^{* * * *}$ & 1.000 \\
\hline 15 & DEBTRATIO & $0.246^{* * * *}$ & $0.232^{* * * *}$ & $0.162^{* * * *}$ & $0.129^{* * * *}$ & $0.179^{* * * *}$ & -0.072 & $0.147^{* * *}$ & $0.197^{* * *}$ & $0.182^{* * * *}$ & 0.016 & $0.074^{*}$ & $-0.157^{* * * *}$ & $-0.121^{* * * *}$ & $0.430^{* * * *}$ \\
\hline
\end{tabular}

Panel B: the Pearson correlation between corporate governance variables and asymmetric information variables

\begin{tabular}{|c|c|c|c|c|c|c|c|c|c|c|c|c|c|c|}
\hline & & 1 & 2 & 3 & 4 & 5 & 6 & 7 & 8 & 9 & 10 & 11 & 12 & 13 \\
\hline 16 & SPREAD & -0.524 & $-0.547^{* * * *}$ & $-0.361^{* * * * *}$ & -0.268 & 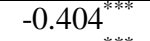 & 0.019 & $-0.358^{* * *}$ & $-0.449^{* * * * *}$ & $-0.335^{* * * 2 *}$ & $-0.132^{* * *}$ & $-0.368^{* * * * *}$ & 0.316 & $0.279^{* * * * * 6}$ \\
\hline 17 & VOLATILITY & $-0.218^{* * * * *}$ & $-0.203^{* * * * *}$ & $-0.171^{* * * * *}$ & $-0.131^{* * * *}$ & $-0.128^{* * * *}$ & $0.118^{* * *}$ & $-0.130^{* * * *}$ & $-0.154^{* * * *}$ & $-0.144^{* * * * *}$ & -0.047 & $-0.120^{* * * * *}$ & $0.076^{*}$ & $0.107^{* *}$ \\
\hline 18 & VOLUME & $0.429^{* * * *}$ & $0.479^{* * *}$ & $0.323^{* * *}$ & $0.242^{* * *}$ & $0.344^{* * * *}$ & 0.048 & $0.263^{* * *}$ & $0.365^{* * *}$ & $0.306^{* * * *}$ & 0.005 & $0.307^{* * *}$ & $-0.272^{* * *}$ & $-0.279^{* * *}$ \\
\hline & & 14 & 15 & 16 & 17 & & & & & & & & & \\
\hline 16 & SPREAD & $-0.785^{* * * * *}$ & $-0.299^{* * * *}$ & 1.000 & & & & & & & & & & \\
\hline 17 & VOLATILITY & $-0.252^{* * * *}$ & $-0.094^{* * *}$ & $0.431^{\text {***** }}$ & 1.000 & & & & & & & & & \\
\hline 18 & VOLUME & $0.698^{* * *}$ & $0.217^{* * *}$ & $-0.595^{* * *}$ & 0.054 & & & & & & & & & \\
\hline
\end{tabular}


Table 5

Corporate Governance and Asymmetric information (Full model)

\begin{tabular}{|c|c|c|c|c|c|c|}
\hline & \multicolumn{2}{|c|}{ SPREAD (+) } & \multicolumn{2}{|c|}{ VOLATILITY (+) } & \multicolumn{2}{|c|}{ VOLUME (-) } \\
\hline Variable & Coef. & SE & Coef. & SE & Coef. & SE \\
\hline (Constant) & 0.057 & 0.152 & 0.055 & 0.176 & $-0.114^{*}$ & 0.062 \\
\hline NONEXESIZE & $-0.331^{* * *}$ & 0.049 & $-0.098^{*}$ & 0.057 & $0.311^{* * * *}$ & 0.064 \\
\hline SPLIT (dummy) & 0.166 & 0.103 & 0.077 & 0.121 & -0.061 & 0.135 \\
\hline NONEXE & -0.031 & 0.070 & 0.059 & 0.081 & 0.086 & 0.091 \\
\hline CHAIR (dummy) & & & & & & \\
\hline NCSIZE & -0.054 & 0.047 & $-0.147^{* * *}$ & 0.054 & 0.058 & 0.061 \\
\hline BOARD & -0.012 & 0.042 & $0.093^{*}$ & 0.049 & $0.114^{* *}$ & 0.054 \\
\hline MEETINGS & & & & & & \\
\hline ACMEETS & $-0.167^{* * *}$ & 0.047 & -0.014 & 0.054 & 0.093 & 0.060 \\
\hline FEMAL & -0.066 & 0.052 & 0.004 & 0.061 & -0.020 & 0.067 \\
\hline TOBOARD & & & & & & \\
\hline CEOBENFITS & $-0.216^{* * *}$ & 0.042 & -0.059 & 0.048 & $0.213^{* * *}$ & 0.053 \\
\hline CEOLONG & 0.153 & 0.117 & -0.022 & 0.138 & -0.050 & 0.147 \\
\hline COMP (dummy) & & & & & & \\
\hline BLOCKOWN & $0.205^{* * *}$ & 0.040 & $0.114^{* *}$ & 0.047 & $-0.147^{* * *}$ & 0.052 \\
\hline DEBTRATIO & $-0.194^{* * *}$ & 0.042 & $-0.108^{* *}$ & 0.049 & 0.036 & 0.054 \\
\hline $\mathrm{N}$ & 318 & & 325 & & 327 & \\
\hline R-Squared & 0.517 & & 0.193 & & 0.228 & \\
\hline
\end{tabular}

Note: SPREAD and VOLATILITY are directly related to asymmetric information but VOLUME is inversely related to asymmetric information. All regression models use the normal score for all continuous variables. All regressions are corrected for heteroskedasticity. The regressions include all the independent variables (including the dummy variables), but exclude variables which had high collinearity. The standard errors SE are reported besides the coefficient Coef. and ***, **, * indicate statistical significance at the $1 \%, 5 \%$, and $10 \%$ levels, respectively. 
Table 6

Corporate Governance and Asymmetric Information (reduced models)

Panel A: Reduced model with main variables

SPREAD (+) VOLATILITY VOLUME (-)

$(+)$

\begin{tabular}{lllllll}
\multicolumn{1}{c}{ Variable } & Coef. & SE & Coef. & SE & Coef. & SE \\
\hline Constant) & -0.005 & 0.143 & 0.012 & 0.175 & 0.039 & 0.075 \\
NONEXESIZE & $-0.339^{* * *}$ & 0.031 & $-0.145^{* * *}$ & 0.041 & $0.323^{* * * *}$ & 0.038 \\
ACMEETS & $-0.221^{* * *}$ & 0.032 & 0.005 & 0.043 & $0.212^{* * * *}$ & 0.039 \\
CEOBENFITS & $-0.184^{* * *}$ & 0.029 & -0.060 & 0.037 & $0.182^{* * * *}$ & 0.035 \\
BLOCKOWN & $0.204^{* * *}$ & 0.027 & $0.060^{*}$ & 0.036 & $-0.171^{* * * *}$ & 0.033 \\
DEBTRATIO & $-0.177^{* * *}$ & 0.028 & $-0.150^{* * *}$ & 0.037 & 0.025 & 0.034 \\
$N$ & 636 & & 646 & & 649 & \\
R- Squared & 0.530 & & 0.158 & & 0.312 & \\
\hline
\end{tabular}

Panel B: Reduced model with alternative variables

SPREAD (+) VOLATILITY VOLUME (-)

$(+)$

\begin{tabular}{lllllll}
\multicolumn{1}{c}{ Variable } & Coef. & SE & Coef. & SE & Coef. & SE \\
\hline (Constant) & -0.018 & 0.145 & 0.035 & 0.166 & 0.053 & 0.057 \\
BSIZE & $-0.333^{* * *}$ & 0.032 & $-0.175^{* * *}$ & 0.041 & $0.220^{* * * *}$ & 0.040 \\
RCMEETS & $-0.148^{* * *}$ & 0.032 & 0.001 & 0.040 & $0.130^{* * *}$ & 0.039 \\
CEOBENFITS & $-0.251^{* * * *}$ & 0.032 & $-0.116^{* * *}$ & 0.040 & $0.233^{* * *}$ & 0.038 \\
LARGEST & $0.136^{* * *}$ & 0.029 & 0.059 & 0.037 & $-0.186^{* * * *}$ & 0.036 \\
OWNER & & & & & & \\
DEBTRATIO & $-0.188^{* * *}$ & 0.030 & $-0.117^{* * *}$ & 0.038 & 0.036 & 0.037 \\
$\boldsymbol{N}$ & 608 & & 617 & & 619 & \\
R- Squared & 0.469 & & 0.163 & & 0.227 & \\
\hline
\end{tabular}

Note: In Panel A, we choose five of the most significant variables from those included in Table 5 one each representing our five hypothesis. Specifically, we expect an inverse relation between asymmetric information and ideal characteristics of the board (NONEXESIZE), activeness of the board (ACMEETS), performance enhancing compensation schemes (CEOBENEFITS) and debt burden (DEBTRATIO) and a direct relation with concentration of insider ownership (BLOCKOWN). In Panel B, for robustness we substitute those variables rejected earlier as they had high collinearity with other variables. In particular we replaced NONEXESIZE with BSIZE, ACMEETS with RCMEETS and BLOCKOWN with LARGESTOWNER. The standard errors SE are reported besides the coefficients Coef. and ${ }^{* * *}, * *, *$ indicate statistical significance at the $1 \%, 5 \%$, and $10 \%$ levels, respectively. 
Table 7

Robustness between corporate governance and asymmetric information: Stability by year

\begin{tabular}{|c|c|c|c|c|c|c|c|c|}
\hline \multicolumn{9}{|c|}{ Panel A: Reduced model with main variables } \\
\hline \multirow[b]{2}{*}{ Variable } & \multicolumn{2}{|c|}{2003} & \multicolumn{2}{|c|}{2004} & \multicolumn{2}{|c|}{2005} & \multicolumn{2}{|c|}{2006} \\
\hline & Coef. & SE & Coef. & SE & Coef. & SE & Coef. & SE \\
\hline (Constant) & $0.429^{* * *}$ & 0.069 & 0.004 & 0.054 & $-0.226^{* * *}$ & 0.052 & $-0.227^{* * *}$ & 0.050 \\
\hline NONEXESIZE & $-0.357^{* * *}$ & 0.080 & $-0.426^{* * *}$ & 0.066 & $-0.309^{* * *}$ & 0.065 & $-0.311^{* * *}$ & 0.052 \\
\hline ACMEETS & $-0.264^{* * *}$ & 0.070 & $-0.228^{* * *}$ & 0.051 & $-0.192^{* * * *}$ & 0.060 & $-0.227^{* * *}$ & 0.052 \\
\hline CEOBENFITS & $-0.155^{* *}$ & 0.077 & $-0.187^{* * *}$ & 0.061 & $-0.148^{* * *}$ & 0.051 & $-0.231^{* * *}$ & 0.058 \\
\hline BLOCKOWN & $0.237^{* * * *}$ & 0.078 & $0.232^{* * *}$ & 0.056 & $0.188^{* * *}$ & 0.058 & $0.195^{* * *}$ & 0.055 \\
\hline DEBTRATIO & -0.062 & 0.067 & $-0.138^{* * * *}$ & 0.052 & $-0.235^{* * *}$ & 0.065 & $-0.206^{* * *}$ & 0.046 \\
\hline$N$ & 102 & & 131 & & 211 & & 192 & \\
\hline R-Squared & 0.411 & & 0.553 & & 0.405 & & 0.540 & \\
\hline \multicolumn{9}{|c|}{ Panel B: Reduced model with alternative variables } \\
\hline \multirow[b]{2}{*}{ Variable } & \multicolumn{2}{|c|}{2003} & \multicolumn{2}{|c|}{2004} & \multicolumn{2}{|c|}{2005} & \multicolumn{2}{|c|}{2006} \\
\hline & Coef. & $\mathrm{SE}$ & Coef. & $\mathrm{SE}$ & Coef. & $\mathrm{SE}$ & Coef. & $\mathrm{SE}$ \\
\hline (Constant) & $0.444^{* * * *}$ & 0.080 & 0.017 & 0.059 & $-0.245^{* * *}$ & 0.056 & $-0.262^{* * * *}$ & 0.050 \\
\hline BSIZE & $-0.260^{* * *}$ & 0.099 & $-0.356^{* * *}$ & 0.068 & $-0.316^{* * *}$ & 0.071 & $-0.379^{* * * *}$ & 0.070 \\
\hline RCMEETS & -0.048 & 0.074 & $-0.155^{* *}$ & 0.069 & $-0.180^{* * * *}$ & 0.057 & $-0.159^{* *}$ & 0.063 \\
\hline CEOBENFITS & $-0.266^{* * *}$ & 0.095 & $-0.304^{* * * *}$ & 0.068 & $-0.203^{* * *}$ & 0.062 & $-0.237^{* * *}$ & 0.064 \\
\hline LARGEST & $0.260^{* * *}$ & 0.106 & $0.180^{* * *}$ & 0.054 & 0.083 & 0.054 & $0.106^{*}$ & 0.057 \\
\hline OWNER & & & & & & & & \\
\hline DEBTRATIO & -0.062 & 0.087 & $-0.144^{* * *}$ & 0.056 & $-0.256^{* * *}$ & 0.067 & $-0.217^{* * *}$ & 0.051 \\
\hline$N$ & 91 & & 120 & & 206 & & 191 & \\
\hline R-Squared & 0.342 & & 0.494 & & 0.359 & & 0.491 & \\
\hline
\end{tabular}

Note: In Panel A, we choose five of the most significant variables from those included in Table 5, one for each of our five hypotheses. Specifically, we expect an inverse relation between asymmetric information and ideal characteristics of the board (NONEXESIZE), board activity(ACMEETS), performance related compensation schemes (CEOBENEFITS) and debt burden (DEBTRATIO) and a direct relation with concentration of insider ownership (BLOCKOWN). In Panel B, for robustness we substitute the variables dropped earlier as they had high collinearity with other variables. In particular we replaced NONEXESIZE with BSIZE, ACMEETS with RCMEETS and BLOCKOWN with LARGESTOWNER. ***, **,* indicate statistical significance at the $1 \%, 5 \%$, and $10 \%$ levels, respectively. 


\section{Table 8}

Robustness between corporate governance and asymmetric information: Stability by company size and by industry classification

\begin{tabular}{|c|c|c|c|c|c|c|c|c|}
\hline \multicolumn{9}{|c|}{ Panel A: Reduced model with main variables } \\
\hline \multirow[b]{2}{*}{ Variable } & \multicolumn{2}{|c|}{ Large } & \multicolumn{2}{|c|}{ Small } & \multicolumn{2}{|c|}{ Industrial } & \multicolumn{2}{|c|}{ Non-Industrial } \\
\hline & Coef. & SE & Coef. & SE & Coef. & SE & Coef. & SE \\
\hline (Constant) & $-0.379^{* * * *}$ & 0.114 & $0.359^{* * * *}$ & 0.101 & 0.069 & 0.144 & -0.059 & 0.143 \\
\hline NONEXESIZE & $-0.351^{* * *}$ & 0.039 & $-0.103^{* *}$ & 0.048 & $-0.239^{* * * *}$ & 0.054 & $-0.345^{* * *}$ & 0.040 \\
\hline ACMEETS & $-0.220^{* * *}$ & 0.039 & $-0.150^{* * *}$ & 0.046 & $-0.233^{* * *}$ & 0.045 & $-0.231^{* * *}$ & 0.043 \\
\hline CEOBENFITS & $-0.072^{* *}$ & 0.036 & $-0.181^{* * *}$ & 0.040 & $-0.299^{* * *}$ & 0.043 & $-0.129^{* * *}$ & 0.038 \\
\hline BLOCKOWN & $0.136^{* * * *}$ & 0.032 & $0.130^{* * * *}$ & 0.041 & $0.175^{* * *}$ & 0.041 & $0.231^{* * *}$ & 0.036 \\
\hline DEBTRATIO & -0.003 & 0.036 & $-0.085^{* *}$ & 0.041 & $-0.094^{* *}$ & 0.041 & $-0.233^{* * *}$ & 0.037 \\
\hline$N$ & 331 & & 305 & & 253 & & 383 & \\
\hline R-Squared & 0.423 & & 0.233 & & 0.545 & & 0.537 & \\
\hline \multicolumn{9}{|c|}{ Panel B: Reduced model with alternative variables } \\
\hline & \multicolumn{2}{|c|}{ Large } & \multicolumn{2}{|c|}{ Small } & \multicolumn{2}{|c|}{ Industrial } & \multicolumn{2}{|c|}{ Non-Industrial } \\
\hline Variable & Coef. & SE & Coef. & SE & Coef. & SE & Coef. & SE \\
\hline (Constant) & $-0.445^{* * *}$ & 0.136 & $0.343^{* * *}$ & 0.088 & 0.095 & 0.153 & -0.094 & 0.141 \\
\hline BSIZE & $-0.266^{* * *}$ & 0.041 & $-0.116^{* *}$ & 0.048 & $-0.189^{* * *}$ & 0.053 & $-0.375^{* * *}$ & 0.042 \\
\hline RCMEETS & $-0.128^{* * *}$ & 0.038 & $-0.098^{* *}$ & 0.046 & $-0.175^{* * *}$ & 0.044 & $-0.132^{* * *}$ & 0.044 \\
\hline CEOBENFITS & $-0.128^{* * *}$ & 0.041 & $-0.231^{* * * *}$ & 0.044 & $-0.325^{* * *}$ & 0.047 & $-0.218^{* * * *}$ & 0.042 \\
\hline LARGEST & $0.111^{* * *}$ & 0.033 & $0.095^{\text {** }}$ & 0.044 & $0.149^{* * *}$ & 0.043 & $0.148^{* * *}$ & 0.038 \\
\hline OWNER & & & & & & & & \\
\hline DEBTRATIO & -0.029 & 0.041 & $-0.086^{* *}$ & 0.042 & $-0.152^{* * *}$ & 0.044 & $-0.216^{* * *}$ & 0.041 \\
\hline$N$ & 318 & & 290 & & 241 & & 367 & \\
\hline R-Squared & 0.292 & & 0.231 & & 46.7 & & 48.7 & \\
\hline
\end{tabular}

Note: In Panel A, we choose five of the most significant variables from those included in Table 5, one for each of our five hypotheses. Specifically, we expect an inverse relation between asymmetric information and ideal characteristics of the board (NONEXESIZE), board activity (ACMEETS), performance related compensation schemes (CEOBENEFITS) and debt burden (DEBTRATIO) and a direct relation with concentration of insider ownership (BLOCKOWN). In Panel B, for robustness we substitute the variables dropped earlier as they had high collinearity with other variables. In particular we replaced NONEXESIZE with BSIZE, ACMEETS with RCMEETS and BLOCKOWN with LARGESTOWNER. ***,**,* indicate statistical significance at the $1 \%, 5 \%$, and $10 \%$ levels, respectively. 